\title{
ART AS A CUSTOM TO IMPROVE ENGINEERING CREATIVITY
}

\author{
M. Kemal GÖKAY ${ }^{1}$, Melek GÖKAY ${ }^{2}$
}

1.Prof. Dr. Konya Technical University. (KTUN), Mining Eng. Dept., Konya, mkgokay(at)ktun.edu.tr, ORCID: 0000-0003-3792-9414

2. Prof. Dr. Necmettin Erbakan University. (NEU), Fine Art Education Dept. Konya, mgokay(at)erbakan.edu.tr, ORCID: 0000-0002-4788-6115

Gokay, M.Kemal. \& Gokay, Melek. “Art as a custom to improve engineering creativity”. idil, 58 (2019 June): s. 713-721. doi: 10.7816/idil-08-58-01

\begin{abstract}
Engineering covers numerous uncertain decision parameters. Engineering plans based on three dimensional earth locations, work and workplace organizations or designing new technological merchandises are some of the duties of engineers. Engineers are asked to respond full options related with scientific knowledge and improvements in their own subject. They should also have ability to perform consulting and controlling activities by obeying work \& workplace safety obligations. They have to grasp and follow all required "engineering responsibilities" in their projects. There are countless influencing aspects on engineering projects. Engineers should have wide perception to handle all scientific, technological, engineering, the art and mathematical (STEAM) features and other shares of tasks in their projects. In design stage, engineers are enquired to act in critical and creative manner to solve real-world, unstructured, burdens. Recently, engineers in all branches, especially in mining industry, have requested more predominately to provide original 3D-plans, robust design products, novel working methods, and practical solutions for technological difficulties (in mines) etc. which all have governed by current social and industrial business conditions. Therefore influences of art on engineering creativities and thinking abilities have been studied here to comprehend its position in engineering education.
\end{abstract}

Anahtar Kelimeler: Art in engineering education, Engineering creativity, Innovations, Art to enhance engineering capacity, STEAM 


\section{Introduction}

Countries which have more dynamic system to evaluate their education curriculums have opportunities to catch current education trends. That's why the importance of critical and creative education in schools might have been realized and recommendations have been gradually implemented in those countries. Ontario (Canada), for example presented different education approach for $21^{\text {st }}$ Century. They have required new capacities for students; "for education systems to emphasize and develop these competencies in explicit and intentional ways through deliberate changes in curriculum design and pedagogical practice. The goal of these changes is to prepare students to solve messy, complex problems including problems we don't yet know about associated with living in a competitive, globally connected, and technologically intensive world", (OPS, 2016).

Engineering education should influence knowledge, ability and behaviour of students. In engineering faculties, students may expect to learn knowledge about; engineering procedures, legislative responsibilities and formulated calculations. These students, in fact, are in deep misunderstanding about engineering jobs. Engineering students should be introduced with their profession at the first days of the colleges. So they realize the importance of scientific knowledge background together with "engineering understanding". They might be taken to industrial sites where engineers are active in production to present their engineering occupational conditions and duties. When we say something about changing technologies, in reality, we are mentioning differentiating industry and occupations together with engineering activities with/without knowing the future situations in industrial businesses. In this modern world, engineers who are graduated with required knowledge, ability and practical experiences have gradually come across more problematic situations if their problem solving abilities are procedural type. Actually, some engineering faculty graduates have enough engineering features, therefore they are more useful for their companies when the comparison have been performed with respect to some other engineering graduates who had attended limited design activities and practical applications. Engineering problems in modern times require social sensitivities on the base of environmental impacts. Engineers must produce much more creative solutions, plans or designs to continue their businesses. Their projects ought to have responsibilities to supply social welfares to local people, so engineers should consider all possible parameters to reach practically applicable results. This requires wide engineering thinking ability which can be handled through engineering education performed with devoted students and lecturers.

\section{Innovative capacity of engineers}

Engineers should offer plans or designs. Some of them include something new and pioneering ideas. Similar types of products cannot hold competitive place in markets for a long time. Innovative new products which have also advantage in production costs dominate the market. Engineers who demonstrate their innovative capacity are always preferred to hire by companies. Planning a flat (building) or a mine is complicated job. Engineers have different considerations to supply valuable resultant plans / design. They should think normal and extraordinary cases for perfect 3 dimensional plans. It is important here that how far the expected cases have distinctly analysed for stabilities. Engineering sense and imagination is important here. It is valuable to mention that types of precautions for fires, hurricanes, flash waters, earthquakes and others make engineers' designs different. Supplying extra passage galleries for emergency exits (in underground mine plans) increases cost of operations in mines. But, in any cases of mine accidents, if mine workers are rescued through these galleries, this will be the differences in "engineering". Thinking in innovative manner in engineering works brings extra responsibilities and considerations on new design works. Design engineers have to be creative to solve related facts and problems as quick as possible. Engineers who do not have proposal for challenging conditions (or opportunities) in their companies are gradually degrading their occupational positions. Projects which are consulting by private or state owned companies have their own circumstances. Engineers (may be as members of a work team) should be ready to offer applicable and economically meaningful solutions. They may either predictably offer similar analyses they performed before or they may start each new project uniquely and they list what are the decision parameters required for exclusive analyses, as far as their imagination and critical considerations extend.

The design considerations here are in some how similar to artists and their blank canvases. Differences in quality of works and aesthetical values among paintings are supplied by artists who determine the value of the artistic products. Artists and engineers implement their visions and thoughts on blank design canvases or pages progressively to reach their final aims. Both cases 
include deep thinking and creativity sessions to produce something different. Most of the products and commodities we use in our daily life including commercial products, houses and cars have gradually changed in time. Basic requirements supplied by industrial products may be similar but the manners and comforts, new products offer have gradually been enhanced. Some engineers have duties in industry outside of the design offices. They have duties in production line to handle safe, healthy and faultless, perfect, working conditions. These engineers force themselves to produce comprehensive working plans in daily and yearly basis which cover also environmentally sensible aspects, product chemical contents, protection of natural resources etc. These facts cannot be evaluated by using only the knowledge obtained in universities. These engineers have to continue their training and education on social sciences, new technologies and new analytic methods while they are working in companies. These activities supply beneficial up-to-date knowledge

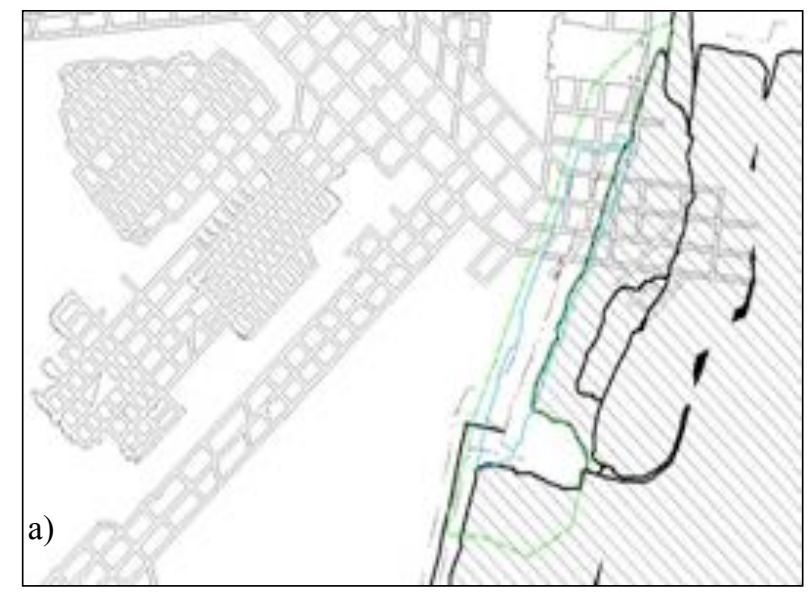

b)

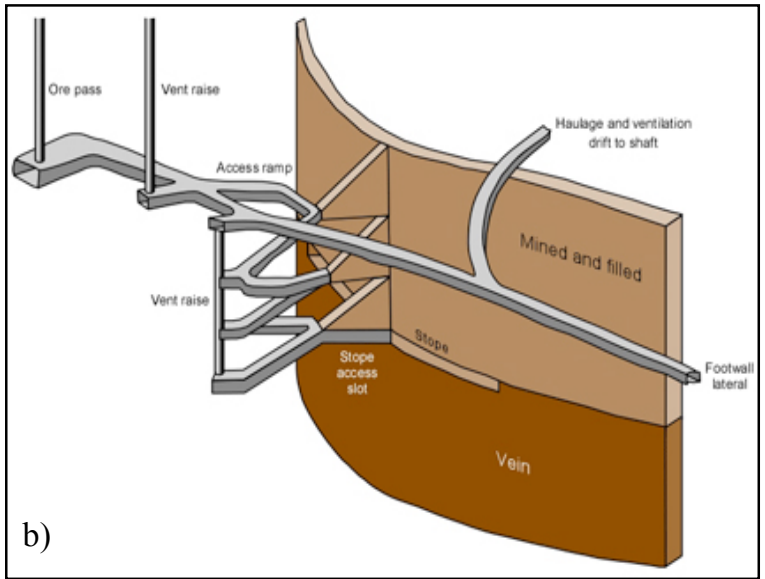

Figure 1. Mine plans in different illustrative manners. a) Two dimensional, scaled mine plans, (Mine Surveyor, 2019), b) Developments in computer hardware and software permits to produce latest 3 dimensional graphics which can be illustrated in different angle of views (NIOSH, 2018).

There are wide ranges of researches on critical and creative thinking. In one of them, Farina (2017) stated that; there is no common definition of critical and creative thinking across disciplines. He wrote that these subjects are considered as; "innovation in education, entrepreneurship in business, or problem solving in mathematics, law and engineering". Creativity in engineering plans and design works can be defined as original or ingenious when engineers present new manners (ideas, methods, or procedures) to solve engineering problems under considerations. Farina (2017) described critical thinking as "self-regulatory judgment; a human cognitive process, involving the use of a core set of cognitive skills-interpretation, analysis, and information for them. However, in order to enhance their imagination and thinking limits beyond the supplied knowledge, they have to practice on thinking, imagine, something new, innovative, in their professions. Sketches and drawings at these phases of creativity play important roles. Engineers present their ideas as plans, design sketches or calculation flow lines. It should be asked here, is it possible to improve engineering capacities, original thinking abilities (in other words their igneous ideas) through engineering education.

For instance, Fig.1 presents two methods to present underground mine galleries and stopes. Implementing computer graphics have steadily helped mine engineers to visualize mine plans as 3D block view for 15 years. Oblique visualization techniques and artistic manners play important role here to produce clear, easy catching, visually rehabilitated $3 \mathrm{D}$ visual blocks representing actual mine operations, galleries, passageways, ramps, stopes, etc. (3D thinking capacity). evaluation, explanation, and self-regulation". He also supplied distinctions in aspects (Table 1) to discriminate the differences between critical and creative thinking. Memorising and remembering certain facts when it is needed in engineering offices or in the field of applications (without personal interpretation) should not be accepted anymore for improved engineering qualifications. Supplying-recalling sets (modules) of engineering information and knowledge may be a model in engineering education. But, this type of knowledge intensive (instructional type) education has graduated engineers who may have not experienced about "engineering thinking" and "engineering decisions". Engineers graduated through this type of education may 
be hired to handle routine control responsibilities for certain companies. However some companies, which have complex jobs, difficult working conditions and full responsibilities, require engineers who should have further possessions to manage their job. Because they are generally asked to provide engineered designs which cover unstructured and uncertain input data. The question which can be bear in mind here is "how engineers became creative to provide methods for a job which nobody dear to offer? Following the methods offered and tested earlier are rather "safe way" in industries. On the other hand, offering new ways, methodologies, have usually brought their own oppositions. Only the innovative companies and innovative directors are welcomed creative ideas which mean new dimensions in engineering businesses like car powered by electric batteries. Is it possible to learn creativity? It is generally possible to say that some people have more capacity in innovative ideas with respect to others. These differences may be the results of their education starting from their birth. However, people can learn to be creative and increase their innovation capacity as well. Farina (2017) wrote that creativity can be taught in classrooms by applying; a) Focus on inquiry teaching, b) Encourage questioning, c) Deal with controversies thereby encouraging discussion, debate and discourse, d) Bring students in to contact with real world problem solving, e) Allow students to take risks, make connections and see relationships, f) Allow for quiet reflection, g) Make the most of unexpected events, h) Allow students to "take a lead"e, i) Help students to develop criteria to make informed judgements, j) Help students value different ways of working.

Table 1. Differences between critical and creative thinking aspects, (Farina, 2017).

\begin{tabular}{|l|l|l|l|}
\hline Critical & Creative & Critical & Creative \\
\hline 1. Analytic, & Generative, & 8. Answers, & An answer, \\
\hline 2. Convergent, & Divergent, & 9. Closed, & Open ended, \\
\hline 3 Vertical, & Lateral, & 10.Linear, & Associated, \\
\hline 4 Probability, & Possibility, & 11. Reasoning, & Speculating, \\
\hline 5. Judgement, & Suspended judgement, & 12. Logic, & Intuition, \\
\hline 6. Hypothesis testing, & Hypothesis forming, & 13. Yes but... & Yes and... \\
\hline 7. Objective, & Subjective, & & \\
\hline
\end{tabular}

\section{Creative thinking in general}

When societies have started to live in more crowded urban areas, engineering activities have been accelerated. Practical solutions and ingenious tools \& equipments supplied by workers, foreman, craftsmen etc. have been altered in different countries according to situations these people have been experienced in everyday lifestyle. In early years of industries, creative foremen \& workers had been hired for their ingenious decisions in their jobs. After technological improvements, machines and work-procedures have gradually been more complicated. Currently, computers and related software have widely used for daily works of engineers. Improvements in calculators, from abacus to mechanically operated calculation-machines are the samples of creativity in engineering. Similarly, there are many different types of designed products surround societies which nobody can think about a life without them. Technological developments in recent years have transferred engineering and related industries rapidly. Influences of new technological methods, new machines, new software etc, have sometimes deep impacts on worldwide businesses.
Therefore, engineers should decide more quickly to coup with these changes. Assume a factory which was producing only dot-matrix printers and did not have any research activities on computer printings. Think about the situations, when this company comes across the laser printers produced by its rival companies? That means any products include creative, innovative, features in engineering businesses generally influence all the markets and certainly the future stability of companies. Students in engineering faculties must be educated in a manner that, these students should think differently and also creative. They ought to analyze scientific backgrounds and facts about their jobs to solve problems while considering all related possible circumstances. This action requires continuous (life-long) self-learning to enhance personal engineering knowledge and visions (critical \&creative thinking). One may ask who is creative, which aspects describe creative people or students. Brand etal. (2015) stated the followings to focus on the differences between intelligent and creative students; "the more facts a student can acquire, recall and reapply the more they are seen as intelligent. Conversely, a creative perspective requires the departure from learnt facts and introduces an emotional and intuitive element to finding new ways of applying 
knowledge and understanding". At this point, it is important to mention Baatar's opinions (RioTinto, 2017) about future workforce in mining industry. According to him; technology, society and markets have dramatically been changed in recent years. He said that; "tomorrow's mining workforce, as in many other industries, will require an increasing focus on problem solving skills, creative thinking and digital savvy". He stressed on the importance of STEM (Science, Technology, Engineering and Mathematics) education system in K12 schools. He said also, "it is estimated that $70 \%$ of future jobs will be STEM related and these will be the key to sustaining economic growth and development". STEM and STEAM programs have gradually been implementing in general education systems to activate students' learning interests, creativity, curiosity, techno-imaginations etal. to obtain deep-learning in required K12 subjects, (Gonzalez \& Kuenzi, 2012; Sousa \& Pilecki, 2013; Henriksen, 2014; Jolly, 2016).

Madden, etal., (2013) studied on interdisciplinary STEAM curriculum and they citied one of their personal communication with industry-leaders in US as well, (H.Land, (2012), Chief Technology Officer for the Information Systems \& Global Solutions, Civil Product Line at Lockheed Martin Corporation, US). Madden etal. wrote that these leaders had been "interested in identifying ways to foster creativity in the context of science to encourage the kind of visionary innovations that will be needed to solve complex problems". That also means that they had presumably preferred employees to obtain those creative ideas for their companies. Madden etal. reported also that these leaders had been requested people who "think-outside-the-box, work in teams with people with diverse expertise, and approach problems both divergently and convergently". Creative thinking features obtained in K12 and university education periods are very important. Therefore curriculum studies in both education systems have gradually been performed to compile required information and data sets. Australian Curriculum Assessment and Reporting Authority, (ACARA) published that; the National Advocates for Arts Education (NAAE) had focused on creativity "in their submission to the Inquiry into innovation and creativity: workforce for the new economy set out the various benefits of an authentic arts education (NAAE, 2017). Specifically, many 21 st century capabilities are supported and enhanced through arts education", (ACARA, 2018). These are important step in public education where original thinking activities, brain storming innovative actions are positively encouraged against education types including state of art knowledge and memorizations. Koivista and Jokinen (2006) supplied clues about so called "Critical autonomous reflective learning". Modern European education policy, the Lisbon strategy, is aimed to provide personal and social developments. In this understanding, people could revolve themselves according to economic tides. They wrote that "competitive economies need autonomous and flexible learners and workers. That is why increasing student autonomy must be one of the goals of every higher education institution in Europe". According to these researchers, students in higher education system should be educated in a way that they ought definitely to develop "independent/autonomous thinking skills". In past, general education curriculums in countries had been purposely structured for common social and educational targets. Current curriculums on the other hand have gradually aimed to graduate more selfdecisive graduates. These graduates will also help to shape new technological improvements in engineering.

\section{Influences of art on innovative thinking}

Innovations and new technologies have been reached after realizing their requirements, market opportunities. Engineering and techno companies sometimes might have overstocked techno-commercial goods, materials, raw materials, know-how procedures etc. Positive advantages in the market they would like to obtain by doing so have steadily been erased by introducing new products and new technologies for 25 years. Therefore companies have recently tried to prepare themselves in quickly changing market conditions. This aim may only be possible by hiring creative engineers who have up-todate knowledge and experiences. This action is crucial for engineering companies which technologically active in business. Engineering students' plan and design abilities are different (Fig. 2). In order to enhance their abilities, what can be done? Researches on art fields have demonstrated that art can be tools for enhancing innovation, creativity, of students. Influences of artistic creativities on engineering designs have also very deep marks to be researched in detail. Why a glasses or bottles of water have so many different shapes. Art and artistic features have been used in engineering products to increase the marketing success. Think about "glass for drinking water or hot drinks", how many different shapes and features on them can be handled? 
a)

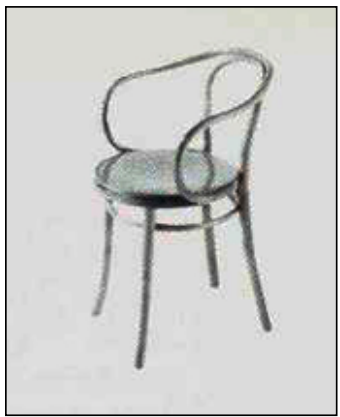

b)

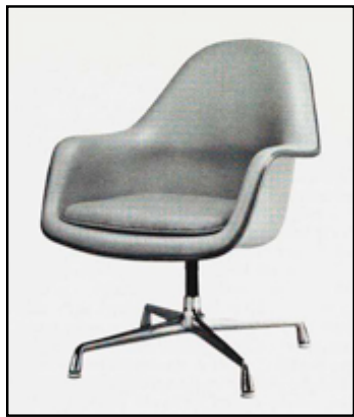

c)

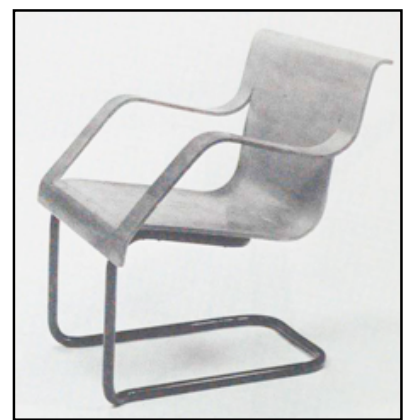

Figure 2. Innovative design products manufactured for similar purposes; a) Armchair, designed by G.Thonet in 1870 (Drexler, 1973), b) Armchair designed by C.Eames in 1971 (Drexler, 1973), c) Armchair (Aalto, 1984).

Aesthetic preferences for marketing might be one of the answers. Others can be related with patents in production procedures. Art can be any form and can be produced by using any materials. That's the way artists have tried to express their visions, ideas, through art. Think the views people can see through their eyes, artist have presented similar views in micro and macro scales to direct (focus) our understanding on a subject. Sometimes they draw or form shapes, three dimensional figures, land reconfigurations etc. to express their ideas. In order to continue to show something which have not presented before, artists (designers or creators) have to be creative in the first hand. When artistic methods of selfexpressions have been analysed, following manners are found effective in art; abstracting, visual metaphors, paradoxes, myths, anomalies and analogies. These methods lead (expand) artists' creative thinking. Artists who would like to use symbolic and semantic values in their products, they have worked on them. They have to analyse conditions of subjects which would like to be expressed through art products, they have also to take consideration of art products' limitations. Organising and arrangements of setback differentiate the art products. Burton, etal., (1999) performed a research in US and they presented that; students educated at schools applied art-rich curriculum obtained higher grades when "Torrance Creative Thinking Ability Tests" were applied to them with respect to schools which were educated according to conventional knowledge based curriculum. These researchers stated that creative students had produced more innovative, creative, and critical ideas in performed cases of problem solving activities. For instance, depleting ore reserves in earth crust forces mine engineers plan their works near socially and environmentally sensitive areas. This might bring extra considerations together with new novel usage of technologies. Gokay\&Gokay (2018) pointed that "mine engineers in near future have to design their mines very differently. Therefore they should be more creative in their projects". Creative thinking outputs accomplished by some artists have been found extraordinary. These levels of brain storming, innovation and original thinking would like to be reached by many engineers as well. Some practices on drawings or paintings might help engineers. Similar to artists, engineers can also be asked to draw something original. When they force themselves to finish their picture, they have been practiced to think about something original. After first assignment, they might be asked again and again, for their original drawings and paints. That means they have to present that, they can think differently from their friends, colloquies, to reach different pictures in these practices. Producing art products are action of self brain storming. Painters start from blank canvas, put paints on canvas in different forms and mix colours until they feel satisfied. The resultant art products can be assumed as the mirror of their visions and dreams. Experiencing this kind of visualisation, drawing pictures of dreams for example, have probably amplified sensing of students and facilitates design ability of engineering students. Electives courses supplied by engineering faculties play important role in students' abilities. Courses related with social activities and art seems beneficial also for engineering students. In some extend enhancing power of these courses are very crucial in students' perceptions of current engineering research and problems. Leonardo da Vinci as a famous artist and engineer had remarkable problem solving considerations. He supplied plans even for self spring-propelled cars and helicopters at his time (Fig. 3). This is the limit of his engineering thinking capacity for that time. It should be bear in mind that engine power and electricity had not known yet at Vinci times. Likewise, Stokley-Byrd, (2019) mentioned about Root-Bernstein \& Root-Bernstein (2001) who had 
written about historical circumstances where arts and innovation ideas play important roles together for some other inventors works as well. They wrote that "Galileo

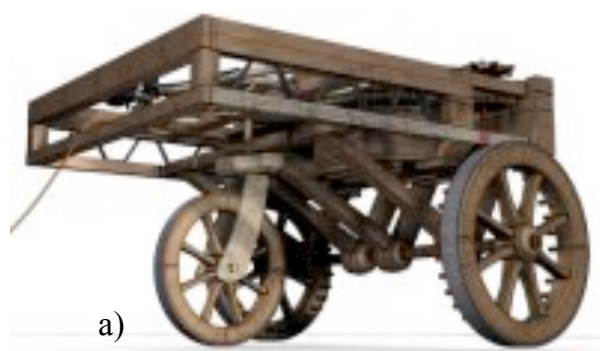

as a poet and literary critic, Einstein as an astute violinist, and Morse as a painter of portraits.

b)

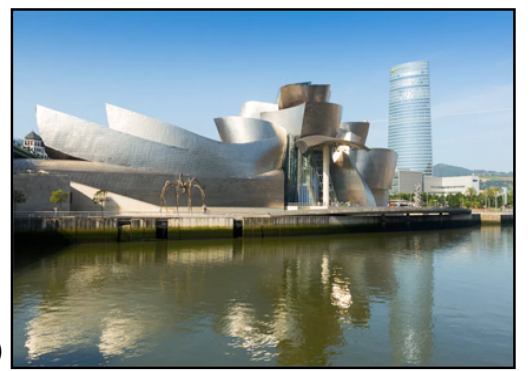

Figure 3. Engineering and art together a) Spring-Propeller Cart had gears, steering and a brake (Vinci, 2018), b) The Guggenheim Museum Bilbao, Museum of modern and contemporary art, museum building designed by F.Gehry and constructed in 1997, (Curbed, 2018).

The original Apple Macintosh Computer team had backgrounds in anthropology, art, history, and poetry". Engineering students of our times should similarly be creative in engineering. They have enough knowledge and enormous information sources to innovate something or some procedures we do not know yet. Faculties therefore should educate students who have been equipped with this internal power to produce and design new things. Engineering companies including mine related ones should ask the questions; where is the ingenuity, cleverness, creativity, dreams to progress in technology related with their businesses? Thus, the answers are directly related with the future market conditions for engineers. There are many more miles to reach our target as societies, humans have to search limits of our sun-system for new raw materials (new mine sides) after mapping related locations of space. That means new directions and aims are waiting for their "real engineers" to be explored.

\section{Conclusions}

Engineering works and workplaces seem complicated but, workers in different engineering branches have understood importance of the decisions taken by their expert engineers. Engineers working as civil servants or production shift managers (including shift engineers) have involved mostly system-controlling, work planning, organising the scheduled works \& workers, workplace safety, quality control and related legislative procedures. In some other companies, engineers have purposely asked to design, plan and evaluate products or subjects according to customers' requests. Thus, engineers have to follow scientific information together with legislative limitation to reach their aims according to occupation types they involved. In all engineering duties, engineers are asked to decide logically with accepting all responsibilities about their decisions. Therefore engineers should have not only the full knowledge of technology \& engineering, they should also have ability to think differently. In order to solve engineering problems and produce valuable \& usable design products, engineers ought to be creative, critical thinker and socially sensitive. Increasing creative and critical thinking capacity of engineering students has recently aimed in engineering faculties.

These featured engineering education is one of the steps which has put extra on STEAM (Science, Technology, Engineering, the Arts, Mathematics) related K12 education. Art in this area is very helpful instrument. Students who have forced to supply something new in their canvas (by drawing) for example, realize what are the basic considerations included in innovation. It has been experienced that art enhance engineering students' views, ideas and thinking capacities. Engineers who are even responsible from routine factory or mine related duties might offer new products \& procedures as far as they have fit to their jobs and they would like to be innovative.

\section{References}

Aalto, A. Alvar Aalto, furniture and glass: [Exhibition]. The Museum of Modern Art, MoMA, New York, US, (Ed; Welley, S.), Red Ink Production Inc. Print, Webpage, www.moma.org/calendar/exhibitions/1792, 1984, 29.

ACARA. Monitoring the effectiveness of the foundation-Year 10. Australian Curriculum. Annual Report, Jan. 2018, ACARA, Australian Curriculum Assessment and Reporting Authority, 2018, 78.

Brand, G., Hendy, L. and Harrison, R. "Mining the gap! Fostering creativity and innovative thinking". The Int. 
Design Technology Conference, DesTech2015, $29^{\text {th }}$ June- $1^{\text {st }}$ July 2015, Geelong, Australia, Procedia Technology, 20, 79-84

Burton, J., Horowitz, R. and Abeles, H. Learning in and through the arts: Curriculum implications. Center for Arts Education Research Teachers College, Columbia University, US, 1999, 46.

Curbed, The Guggenheim Museum Bilbao, Museum of modern and contemporary art. Curbed - The 17 most beautiful museums around the world, Webpage: www.curbed.com /2017/2/23/14690114/best-museums-worldarchitecture, Retrieved Apr. $8^{\text {th }} 2018$.

Drexler, A. Charles Eames: furniture from the design collection, The Museum of Modern Art, MoMA, New York, ISBN 0-87070-314-5, Webpage, www.moma.org/ calendar/exhibitions/1712, 1973, 63.

Farina, M. Critical thinking and creative thinking, Seminar 3. Dr. Mirko Farina's seminars on critical thinking, King's College, London, Feb. 13-18 $8^{\text {th }} 2017,62$.

Gokay, M.K. and Gokay, M. "Art to graduate more innovative mining engineering students". Int. Journal of Environmental trends (IJENT), 2018, 2, 1, 25-34.

Gonzalez, H.B. and Kuenzi, J. Science, Technology, Engineering, and Mathematics (STEM) Education: A Primer. Congressional Research Servise, 7-5700, R42642, CRS Report for Congress, 2012, US.

Henriksen, D. "Full STEAM ahead: Creativity in excellent STEM teaching practices". The Steam Journal, 2014, 1, 2, Article 15, doi: 10.5642/steam.20140102.15

Jolly, A. STEM vs. STEAM: Do the arts belong?, www.wiki-zero.com, EdWeek.org. Education Week: Teacher. Retrieved 6th Sep. 2016.

Koivista, M. and Jokinen, L. Becoming a more critical, autonomous, reflective learner. PRILHE-Promoting Reflective Independent Learning in HE, Student Handbook, The University of Warwick, UK. 2016, 42.

NAAE. Submission to the inquiry into innovation and creativity: workforce for the new economy. Retrieved from Parliament of Australia: 2017, https://www.aph.gov.au/
Parliamentary_Business/Committees/House/Employment_Edu cation_and_Training/Innovationandcreativity/Submissions.

Madden, M., Baxter, M., Beauchamp, H., Bouchard, K., Hobermas, D., Huff, M., Plague, G. "Rethinking STEM education: An interdisciplinary STEAM curriculum". Complex adaptive Systems (Ed. Dagli, C.H), Procedia Computer Science, 2013, 20, 541-546. doi:10.1016/j.procs.2013.09.316

Mine Surveyor. Statutory (Stat) plans, General mine surveying duties, Webpage, www.minesurveyor.net/gsstats.php, Retrieved May $4^{\text {th }} 2019$.

NIOSH. Mining Feature: Deep metal mine fatality raises questions on use of cemented fill, Webpage, https://www.cdc.gov/niosh/mining/features/deepmetalfatality.h tml, Retrieved Apr. $8^{\text {th }}$ 2018, National Institute for Occupational Safety and Health, NIOSH, Mining Program, Centers for Disease Control and Prevention, US.

OPS. Towards defining $21^{\text {st }}$ Century competencies for Ontorio, Phase 1, Foundation document for discussion, Winter 2016 edition, ISBN 978-1-4606-5339-0 (pdf), Canada, Retrieved Feb. $8^{\text {th }} 2019$, p70.

RioTinto. What will the mining workforce of the future look like?, RioTinto Company webpage, www.riotinto. com/ourcommitment/spotligth-18130_22976.aspx, Update Sep. $14^{\text {th }} 2017$.

Root-Bernstein, R., \& Root-Bernstein, M. Sparks of genius: The 13 tools of the world's most creative people. New York, NY: 2001, Houghton Mifflin.

Sousa, D., \& Pilecki, T. From STEM to STEAM: Using brain-compatible strategies to integrate the arts. Thousand Oaks, CA: 2013, Corwin Press.

Stokley Byrd, L. A study of an arts integration curriculum and its impact on academic achievement, $\mathrm{PhD}$ Thesis, 2019, Graduate Faculy of the University of South Alabama, US, 161.

Vinci. Leonardo da Vinci design, Spring-propelled cart, (Image: Institute and Museum of the History of Science, Florence), Webpage: http://www.abc.net.au/science/news/ stories/s1094767.htm, Retrieved Apr. $8^{\text {th }} 2018$. 


\title{
MÜHENDİSLIK YARATICILIĞINI GELISTTİRMEDE SANATIN YERI
}

\author{
M. Kemal GÖKAY ve Melek GÖKAY
}

Özet

Mühendislik uygulamaları yapılırken, sonucu ve kararları etkileyen birçok belirsiz karar parametresi bulunur. Bu uygulamalarda; üç boyutlu lokasyon koordinatlarının temini ve gösterilmesi; iş ve işyeri organizasyonu veya yeni teknolojik ürün tasarımı mühendislerin yürütmekle yükümlü olduğu görevlerdendir. Mühendisler sorumlu oldukları branşlarla ilgili bilimsel bilgileri ve gelişmeleri yakından izleyerek, kendilerine sorulanlara cevap vermek zorundadırlar. Ayrıca alanlarıyla ilgili müşavirlik ve kontrolörlük işlevlerini iş \& işyeri güvenliği yükümlülüklerine göre yürütme kapasitesine sahip olmalıdırlar. Sorumlu oldukları projelerde "mühendislik sorumluluklarının" bilincinde olmaları ve bu sorumlulukları yerine getirmeleri icap eder. Mühendislik projelerinde sonucu etkileyen sayısız alt konu başlı̆ğ ve faktörler vardır. Mühendisler projelerinde birçok farklı konuyu ve etkileyen parametrelerin durumunu düşünürken, STEAM kapsamına da giren; bilim, teknoloji, mühendislik, sanat ve matematik alanlarının konu başlıklarını da ele almalıdırlar. Mühendislerden ele aldıkları düzensiz, kurallara uymayan, gerçek-dünyaya ait mühendislik problemlerini çözmek için tasarım yaparken, eleştirel ve yaratıcı düşünmeleri istenmektedir. Son zamanlarda bütün mühendislik branşlarında, özellikle madencilik endüstrisinde, mühendislerden özellikle istenen iş ve konular; 3B planlar, kalıcı-tutarlı tasarım ürünleri, yenilikçi çalışma yöntemleri, (madenlerdeki) teknolojik zorluklara karşı pratik çözümler vb. şeklinde sıralanabilir. Bütün bu konuların çözümü sırasında mühendislerin, sosyal, endüstriyel ve içinde bulundukları mühendislik dalının çalışma şartlarını düşünerek çözüm üretmeleri gerekecektir. Bu nedenle, sanatın mühendislik yaratıcılığına ve mühendisçe düşünme yeteneğine katkısı, bu çalışma kapsamında incelenerek sanatın mühendislik eğitimindeki yeri araştırılmıştır.

Anahtar Kelimeler: Mühendislik eğitiminde sanat, Mühendislik yaratıcılığı, İnnovasyon, Mühendislik kapasitesini genişletmede sanat, STEAM 